\title{
Nutrients, primary production and microbial heterotrophy in the southeastern Chukchi Sea: Arctic summer nutrient depletion and heterotrophy
}

\author{
G. F. $\operatorname{Cota}^{1, *}$, L. R. Pomeroy ${ }^{2}$, W. G. Harrison ${ }^{3}$, E. P. Jones ${ }^{3}$, F. Peters ${ }^{4}$, \\ W. M. Sheldon, $\mathrm{Jr}^{2}$, T. R. Weingartner ${ }^{5}$ \\ ${ }^{1}$ Graduate Program in Ecology, University of Tennessee, Knoxville, Tennessee 37996-1610, USA \\ ${ }^{2}$ Institute of Ecology, University of Georgia, Athens, Georgia 30602-2202, USA \\ ${ }^{3}$ Bediord Institute of Oceanography, Dartmouth, Nova Scotia, Canada B2Y 4A2 \\ ${ }^{4}$ Institut de Ciències del Mar (CSIC), Passeig Joan de Borbó, s/n, E-08039 Barcelona, Catalunya, Spain \\ ${ }^{5}$ Institute of Marine Science, University of Alaska, Fairbanks, Alaska 99775, USA
}

\begin{abstract}
In August 1993, we measured photosynthesis, chlorophyll a, bacterial secondary production, microbial community respiratory rate, bacterial abundance, dissolved free amino acids, nitrate, phosphate, silicate, and dissolved oxygen in the eastern Chukchi Sea. Our cruise track was mostly in loose pack ice exceeding $50 \%$ ice cover, with heavier ice cover near $75^{\circ} \mathrm{N}$. We sampled over the continental shelf and slope, in deep water in the Canadıan Basin, and over the Chukchi Cap. Primary production was highest over the upper continental slope, averaging $748 \mathrm{mg} \mathrm{C} \mathrm{m}^{-2} \mathrm{~d}^{-1}$ In deep water and heavier ice cover in the Canadian Basin, primary productivity averaged $123 \mathrm{mg} \mathrm{C} \mathrm{m}^{-2} \mathrm{~d}^{-1}$. However, microbial community respiratory rates averaged $840 \mathrm{mg} \mathrm{C} \mathrm{m}^{-2} \mathrm{~d}^{-1}$ over the upper slope and $860 \mathrm{mg} \mathrm{C}$ $\mathrm{m}^{-2} \mathrm{~d}^{-1}$ in the Canadian Basin. Nitrate was virtually depleted in the upper mixed layer, suggesting some nutrient limitation and dependence on regenerated ammonium in late summer. This is supported by $\mathrm{f}$-ratios ranging from 0.05 to 0.38 . Estimates of annual primary production of organic carbon, both from our ${ }^{14} \mathrm{C}$ and ${ }^{13} \mathrm{C}$ assimilation measurements and from the supersaturation of dissolved oxygen in the upper mixed layer at all stations, suggest that significant primary production occurs well beyond the continental shelves out into the so-called perennial pack ice. Respiratory activity in the upper mixed layer exceeded primary productivity at the deep-water stations, as it often does in summer oligotrophic conditions at lower latitudes. These observations suggest that rates of both autotrophic and heterotrophic biological activity in the upper mixed layer of the deep waters of the Arctic Ocean may be considerably higher than suspected and should be incorporated into models of polar processes.
\end{abstract}

KEY WORDS: Arctic Primary production - Microbial heterotrophy Respiration Oxygen - Nutrients

\section{INTRODUCTION}

Previous investigations in the central basins of the Arctic Ocean, especially those done at ice camps (English 1961), have tended to suggest very low rates of photosynthesis in the water column, leading some investigators to conclude that biological processes

\footnotetext{
- Present address: Center for Coastal Physical Oceanography, Old Dominion Unjversity, Norfolk, Virginia 23529, USA.

E-mail:cota@ccpo.odu.edu
}

have little influence on the concentrations of oxygen, phosphate, nitrate, and silicate in the water beyond the continental shelves. Because direct measurements of primary production have been limited almost entirely to the continental margins, most estimates of primary production for the Arctic basin as a whole have been indirect estimates of new production (e.g. Macdonald et al. 1987, Björk 1990), sometimes with the stated assumption that regeneration of nutrents in situ in the water is insignificant (Jones \& Anderson 1986). Our data suggest otherwise, and we show that microbial 
activity, both autotrophic and heterotrophic, must be taken into account for a full explanation of seasonal changes in the vertical distribution of oxygen, nitrate, and phosphate in the upper mixed layer and the upper halocline. Eren less consideration has been given to microbial processes in the central basins of the Arctic Ocean, although extensive investigations of microbial processes at high latitudes in Baffin Bay and the Canadian archipelago have demonstrated their significance (Harrison et al. 1985, 1987, Harrison 1986, Platt et al. 1987).

The Arctic Ocean is a varied environment with definable subregions (e.g. Lyakhin \& Rusanov 1980). A general circulation and throughput of the upper water masses is now well recognized, but its time scale, while still controversial, is certainly long enough so that distinctive physical, chemical, and biological processes may result from regional and seasonal differences in ice cover, wind fields, and water movement. The Chukchi Sea varies from moderate, and in part seasonal, ice cover in the south to extensive, multi-year ice toward the North Pole. The Anadyr Current brings nutrient-rich water into the Chukchi Sea through the Bering Strait, making the southwestern Chukchi Sea one of the most biologically productive regions in a largely oligotrophic body of water (McRoy 1993). Information on the Chukchi Sea north of the ice-free coastal region has been relatively scant. In August 1993, the ANWAP (Arctic Nuclear Waste Assessment Program) program provided an opportunity to collect a range of biological and chemical data between the Alaskan shelf and $75^{\circ} 22^{\prime} \mathrm{N}$, aboard the icebreaker U.S. Coast Guard 'Polar Star'. We encountered late summer conditions and measured primary productivity, bacterial. secondary productivity, inorganic nutrients, community respiratory rates, and dissolved oxygen.

\section{METHODS}

Sampling procedures. Nutrient and oxygen concentrations were determined throughout the water column at 45 to 55 stations, while phytoplankton chlorophyll biomass was measured only in the upper $150 \mathrm{~m}$ at most stations. Carbon fixation, nitrogen uptake and bacterial productivity were measured in surface waters $(<75 \mathrm{~m})$ at selected morning stations. Note that duplicate points on Fig 1 (e.g. E1 and E3) correspond to sequential morning casts at the same nominal alphanumeric station. Routine sampling at morning productivity stations included continuous vertical profiles of temperature, salinity, and fluorescence with a Sea-Cat CTD (conductivity, temperature, depth) profiler, fluorometer, and Secchi disk followed by a second cast with a SBE-911 CTD and. rosette. Discrete samples were collected with $10 \mathrm{l}$ go-flo Niskin bottles for nutrient concentrations $\left[\mathrm{NO}_{3}, \mathrm{Si}(\mathrm{OH})_{4}\right.$ and $\left.\mathrm{HPO}_{4}\right]$, chlorophyll a (chl a), particulate organic carbon and nitrogen. and a variety of experiments. Optical depths were estimated with the Secchi disk and the upper 7 depths corresponded to $100,50,30,15,5,1$, and $0.1 \%$ of surface irradiance. The $0.1 \%$ light level averaged $37 \pm 13 \mathrm{~m}$ (n = 12) and ranged from 25 to $61 \mathrm{~m}$ throughout the cruise. Samples from nonexperimental stations were collected at standard water depths.

Inorganic nutrients. Duplicate unfiltered seawater samples taken for nutrient analyses were collected in well-rinsed, acid-washed $30 \mathrm{ml}$ plastic bottles. Samples were frozen immediately and kept frozen until they were analyzed at the Bedford Institute of Oceanography, about 3 mo later, with an AutoAnalyzer using standard techniques (Parsons et al. 1984). Replicate analyses almost always agreed to within $5 \%$, and many agreed to within $1 \%$.

Chlorophyll. Chl a was determined fluorometrically (Holm-Hansen et al. 1965) by filtering 100 to $250 \mathrm{ml}$. seawater samples through $25 \mathrm{~mm}$ Whatman GF/F glass fiber filters. The filters were placed in vials on ice, sonicated in $90 \%$ acetone for $10 \mathrm{~min}$, extracted for $20 \mathrm{~min}$ more, and then analyzed immediately. Extracted fluorescence was measured before and after acidification (5\% HCl) with a Turner Designs model 10 fluorometer. calibrated with commercially purified chl a (Sigma).

Primary production and nutrient uptake. Primary productivity was measured by ${ }^{14} \mathrm{C}$ (carbon) fixation with simulated in situ (SIS) incubations. Isotope stocks were prepared according to the recommendations of Fitzwater et al. (1982). Our SIS incubator had neutral density and/or blue plastic filters (CineMill) to simulate in situ irradiance spectra vertically over the euphotic zone; it was cooled with flowing surface seawater. Two sets of samples from each of the 7 optical depths were placed in $280 \mathrm{~m} . \mathrm{l}$ polycarbonate bottles, inoculated with $370 \mathrm{kBq}{ }^{14} \mathrm{C}-\mathrm{NaHCO}_{3}$, and one set was incubated for 6 to $8 \mathrm{~h}$ (morning to afternoon) and the other set for 22 to $26 \mathrm{~h}$ (morning to morning). Total activity added and particulate adsorption were measured at time equals zero in parallel samples. Particulate material was harvested on $25 \mathrm{~mm}$ Whatman GF/F filters and rinsed with 5 to $10 \mathrm{mI}$ of $0.01 \mathrm{~N} \mathrm{HCl}$ in filtered seawater to remove inorganic carbon. Radioactivity was assayed by liquid scintillation counting and corrected for particulate adsorption at zero time, background, and counting efficiency. Short-term ( 6 to $8 \mathrm{~h}$ ) values for primary production were 1.75 times higher, on average, than day-long incubations. Water temperature in the incubator and incident photosynthetically active radiation $\left(I_{0} \mathrm{PAR}=400\right.$ to $\left.700 \mathrm{~nm}\right)$ above the incubator were measured continuously with a Licor model 1000 15 thermistor and Licor model SA-190 cosine collector, 
respectively. Both variables were recorded at $5 \mathrm{~min}$ intervals with a Licor model LI-1000 data logger

Parallel SIS incubations with the same morning water samples were used in experiments to measure the simultaneous uptake rates of ${ }^{15} \mathrm{~N}-\mathrm{NO}_{3},{ }^{15} \mathrm{~N}-\mathrm{NH}_{4}$. and ${ }^{13} \mathrm{C}-\mathrm{HCO}_{3}$. Heavy isotope-enriched (95 to $99 \%$ ) solutions of $\mathrm{H}^{13} \mathrm{CO}_{3}, \mathrm{~K}^{15} \mathrm{NO}_{3}$ or $\left({ }^{15} \mathrm{NH}_{4}\right)_{2} \mathrm{SO}_{4}$, were added to $535 \mathrm{ml}$ polycarbonate bottles at concentrations of $\sim 0.05$ to $0.1 \mu \mathrm{M}\left(\mathrm{NO}_{3}, \mathrm{NH}_{4}\right)$ and $\sim 0.2 \mathrm{mM}\left(\mathrm{CO}_{2}\right)$ and were incubated for 6 to $8 \mathrm{~h}$. Samples were then filtered onto precombusted Whatman GF/F glass fiber filters and dried at $60 \% \mathrm{C}$ for later analyses of ${ }^{15} \mathrm{~N}$ and ${ }^{13} \mathrm{C}$ enrichment of particles and for concentrations of particulate organic carbon (POC) and particulate organic nitrogen (PON) using a Tracermass Stable Isotope Analyzer (Europa Scientific). Nitrogen and carbon uptake rates were determined using equations described in Dugdale \& Goering (1967) for ${ }^{15} \mathrm{~N}$ and Hama et al. (1983) for ${ }^{13} \mathrm{C}$.

f-ratios. Two approaches were used to estimate fratios. In the first, uptake of ${ }^{15} \mathrm{NO}_{3}$ was converted to the Redfield ratio carbon equivalent and compared with primary production measurements made at the same time. In the second, an assumed ammonium concentration of $0.1 \mu \mathrm{M}$ was used to compute $\mathrm{NO}_{3}$ uptake/ $\mathrm{NO}_{3}+$ $\mathrm{NH}_{4}$ uptake. Results from the 2 approaches are substantially in agreement

Community respiratory rates. Multiple $125 \mathrm{ml}$ Winkler bottles were filled from the bottom and overflowed for more than 1 volume of the bottle. Six bottles were fixed for Winkler titration initially and additional sets of 6 bottles were placed immediately in dark refrigerators kept at sea temperature (usually $-1.4^{\circ} \mathrm{C}$ ). Temperature in the refrigerators was monitored continuously with electronic max-min thermometers. Sets of bottles were fixed and titrated at approximately 24 and $48 \mathrm{~h}$ intervals. Titration was performed with a Mettler DL-21 titrator, using a potentiometric end point. This 3-point analysis permitted us to inspect the data for departures from linearity which might result from the growth or death of microbial populations during incubation (Pomeroy et al. 1994). Data that departed substantially from linearity were discarded.

Dissolved oxygen. Water from all the depths that were sampled was collected from the rosette and titrated as described above. Because supersaturation was the norm in the upper mixed layer, every effort was made to collect and fix the samples quickly, with minimal temperature change. The precision of replicates was $\pm 0.5 \mu \mathrm{M} \mathrm{O}_{2}(=0.4 \mu \mathrm{M} \mathrm{C})$

Dissolved free amino acids. At selected stations, water was taken directly from Niskin samplers in a new $50 \mathrm{ml}$ syringe. The first $10 \mathrm{ml}$ were expelled through a $0.2 \mu \mathrm{m}$ Anotec ${ }^{\circ}$ filter cartridge to wash the filter, and $<10 \mathrm{ml}$ were collected in a fired glass vial
Three such subsamples were collected from each Niskin sampler. The vials were placed in a freezer and were returned without thawing to our home laboratory for analysis by high performance liquid chromatography following the general precolumn derivatization procedure of Lindroth \& Mopper (1978) and Mopper \& Lindroth (1982). We followed the specific procedures of Henrichs \& Williams (1985), except that samples were thawed at $4^{\circ} \mathrm{C}, 2 \mathrm{ml}$ subsamples were derivatized, and $300 \mu$ l were injected. Derivatized primary amino acids were separated in a $250 \times 4.6 \mathrm{~mm}$ cartridge-style column (Alltech) packed with Spherisorb ODS-1, 5 mm (Phase Separation) and detected using a Kratos FS970 Spectrofluoromonitor. The amino acids quantified were: aspartic acid, glutamic acid, serine, histidine + threonine + glycine (co-eluted), alanine, tyrosine, arginine, methionine, valine, phenylalanine, isoleucine, leucine, and lysine.

Bacterial secondary production. Because samples were being collected by other investigators to measure naturally occurring tritium during the ANWAP cruise, the use of tracer concentrations of tritiated compounds was not a compatible activity. Instead, we estimated bacterial secondary production from the uptake of ${ }^{14} \mathrm{C}$ l-leucine. On a previous cruise we had compared uptake of ${ }^{14} \mathrm{C}$-and ${ }^{3} \mathrm{H}$-leucine and found no significant difference, except that the sensitivity was lower with the carbon label because of its lower specific activity (data not shown). Triplicate sets of $10 \mathrm{ml}$ seawater samples were pulsed with $10 \mathrm{nM}{ }^{14} \mathrm{C}$-leucine $(1.1 \mathrm{kBq})$ for periods of 1,3 , and $6 \mathrm{~h}$ at sea temperature in a water bath, and protein was extracted with $5 \%$ trichloracetic acid at $95^{\circ} \mathrm{C}$ for $30 \mathrm{~min}$. Precipitated protein was collected on a $0.2 \mu \mathrm{m}$ cellulose butyrate membrane filter, and the filter was dried and stored in a desiccator for later liquid scintillation counting.

Leucine uptake rates were converted to bacterial carbon production according to Simon \& Azam (1989), correcting for internal pool dilution by a factor of 2 . While, with one exception, external leucine pool concentrations were $<10 \mathrm{nM}$ (Table 1 ), it is possible that we failed to achieve $V_{\max }$ with that leucine concentration (viz. Logan \& Fleury 1993, van Looij \& Riemann 1993, Pomeroy et al. 1995). Thus, our estimates of bacterial secondary production are conservative and may underestimate it. If bacterial secondary production was underestimated, that may also result in overestimates of the turnover time of dissolved free leucine.

Bacterial abundance. Samples were fixed with alkaline Lugol's solution, followed by buffered formalin, and were refrigerated. The samples were then returned to our home laboratory, where they were stained with acridine orange and counted by epitluorescence microscopy (Hobbie et al. 1977) within 2 wk of collection at sea. 
Table 1. Total dissolved free amino acids (LDFAA) and leucine concentration, uptake and turnover at selected stations in the Chukchi Sea, August 1993

\begin{tabular}{|c|c|c|c|c|c|c|c|c|}
\hline Stn & $\begin{array}{l}\text { Latitude } \\
\qquad \mathrm{N}\end{array}$ & $\begin{array}{l}\text { Longitude } \\
\text { W }\end{array}$ & $\begin{array}{l}\text { Total } \\
\text { depth } \\
(\mathrm{m})\end{array}$ & $\begin{array}{c}\text { Sample } \\
\text { depth } \\
\text { (m) }\end{array}$ & $\begin{array}{l}\text { EDFAA } \\
(\mathrm{nM})\end{array}$ & $\begin{array}{c}\text { Leucine } \\
\text { concentration } \\
\text { (nM) }\end{array}$ & $\begin{array}{l}\text { Leucine } \\
\text { uptake } \\
\left(\mathrm{pM} \mathrm{h}^{-1}\right)\end{array}$ & $\begin{array}{c}\text { Leucine } \\
\text { turnover } \\
\text { (h) }\end{array}$ \\
\hline E12 & $72^{\circ} 29.9^{\prime}$ & $159^{\circ} 48.4^{\prime}$ & 40 & 4 & 69 & 2.2 & 5.36 & 410 \\
\hline E12 & & & & 16 & 173 & 5.4 & 8.43 & 651 \\
\hline E6 & $73^{\circ} 053^{\prime}$ & $158^{\circ} 45.1^{\prime}$ & 1450 & 6 & 34 & 1.1 & 2.04 & 539 \\
\hline E6 & & & & 21 & 52 & 2.1 & 1.84 & 1141 \\
\hline E6 & & & & 45 & 33 & 1.7 & 1.44 & 1181 \\
\hline E5 & $73^{\circ} 1.2 .4^{\prime}$ & $158^{\circ} 28.4^{\prime}$ & 1880 & 5 & 88 & 1.4 & 6.77 & 207 \\
\hline E5 & & & & 19 & 1473 & 192.5 & 4.05 & 42778 \\
\hline G6 & $71^{\circ} 24.3^{\prime}$ & $157^{\circ} 28.1^{\prime}$ & 113 & 10 & 34 & 1.4 & 1.01 & 1386 \\
\hline G6 & & & & 30 & 191 & 6.3 & 1.05 & 600 \\
\hline G6 & & & & 50 & 147 & 2.8 & 0.92 & 305 \\
\hline B1 & $72^{\circ} 00.4^{\prime}$ & $165^{\circ} 18.4^{\prime}$ & 43 & 1.4 & 36 & 1.3 & 6.68 & 195 \\
\hline B1 & & & & 14 & 135 & 3.7 & 5.19 & 713 \\
\hline B1 & & & & 30 & 29 & 0.6 & 5.70 & 105 \\
\hline
\end{tabular}

\section{RESULTS}

The E section is the most detailed of the ANWAP cruise, running NNE from a point near $72.5^{\circ} \mathrm{N}$ on the continental shelf north of Icy Cape, across the continental slope to a depth exceeding $3800 \mathrm{~m}$ in the Canadian Basin (Fig. 1). Most of this section was in $50 \%$ or greater cover of mixed first-year and multi-year ice. The less detailed $\mathrm{D}$ section then runs NW across the Chukchi Cap to $75.5^{\circ} \mathrm{N}$ in depths of 1000 to $2000 \mathrm{~m}$. Percent ice cover and ice floe thickness increased northward along this section, with multi-year ice increasing in relative abundance to the north. The $\mathrm{C}$ section runs SW up the continental slope to the shelf break, while the B section, partly in open water, runs

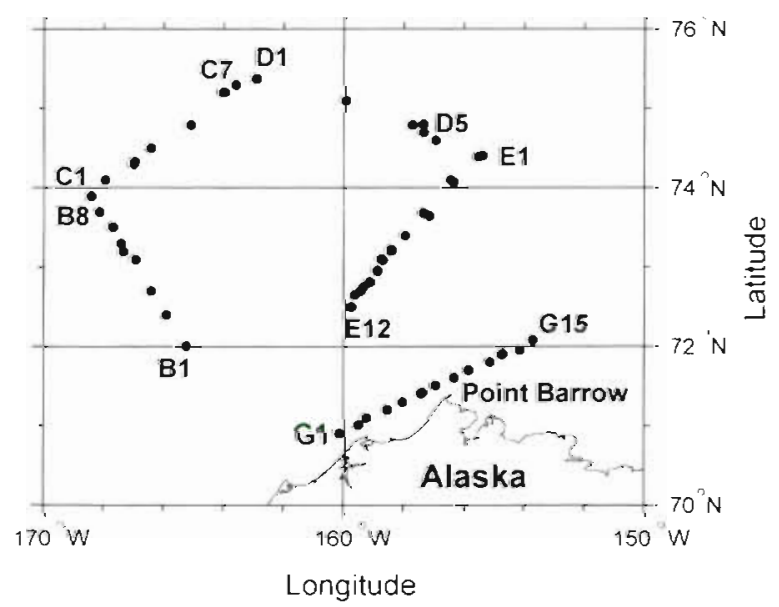

Fig. 1. Cruise track for U.S. Coast Guard 'Polar Star' from 29 July to 15 August 1993. Sampling sequence was E, D, C, B, G. See Tables 1 and 2 for experimental station locations and depths
SSE across the continental shelf to $72^{\circ} \mathrm{N}$. The G section runs NE along the inner continental shelf past Point Barrow, Alaska, and down the Barrow Canyon to a depth of $1660 \mathrm{~m}$.

Beneath the melting pack ice, a surface mixed layer of water of reduced salinity was 15 to $20 \mathrm{~m}$ in thickness, followed by the halocline-nutricline, extending down to $150 \mathrm{~m}$ (Fig. 2). Nitrate was nearly depleted in the upper 10 to $20 \mathrm{~m}$ at most stations over the continental shelf and varied from $<0.1$ to $0.4 \mu \mathrm{M}$ in the upper 20 to $25 \mathrm{~m}$ offshore. Nitrate exceeded $0.5 \mu \mathrm{M}$ in near surface waters only at Stns E5 and E6.

\section{Chlorophyll and photosynthesis}

There was always a subsurface chlorophyll maximum which exceeded $1 \mathrm{mg} \mathrm{m}^{-3}$ over the continental shelf, dropping below 1 approximately at the shelf break. Over the continental slope, the chlorophyll maximum was at the top of the cold halocline at a depth of 30 to $40 \mathrm{~m}$, with maximum concentrations ranging from $1 \mathrm{mg} \mathrm{m}^{-3}$ near the shelf break to $0.1 \mathrm{mg}$ $\mathrm{m}^{-3}$ over deep water in the Canadian Basin (Figs. 1 \& 2). Stations over the upper continental slope having high chlorophyll or high photosynthesis were C6, E5 and $\mathrm{G} 13$; these same stations also showed high nitrate concentrations relatively near the surface. The general distributions of chlorophyll and nitrate suggest a postbloom condition, but with some kind of vertical advection having taken place recently on the upper continental slope near Stns E5 and E6.

Mean profiles through the euphotic zone showed that the maxima for daily (22 to $26 \mathrm{~h}$ incubations) primary productivity and biomass-specific productivity were 
Fig. 2. (a) Temperature, (b) salinity, (c) nitrate, (d) dissolved oxygen, (e) chlorophyll, and (f) primary productivity (based on 22 to $26 \mathrm{~h}$ incubations) in the upper water column along the E section from the outer continental shelf $(<50 \mathrm{~m})$ to the Canadian Basin (>3800 m). The approximate depth of $100 \%$ saturation for dissolved oxygen is shown by the broken line at $385 \mu \mathrm{M}$ and includes a small bolus of water centered around $85 \mathrm{~m}$ at Stn E5

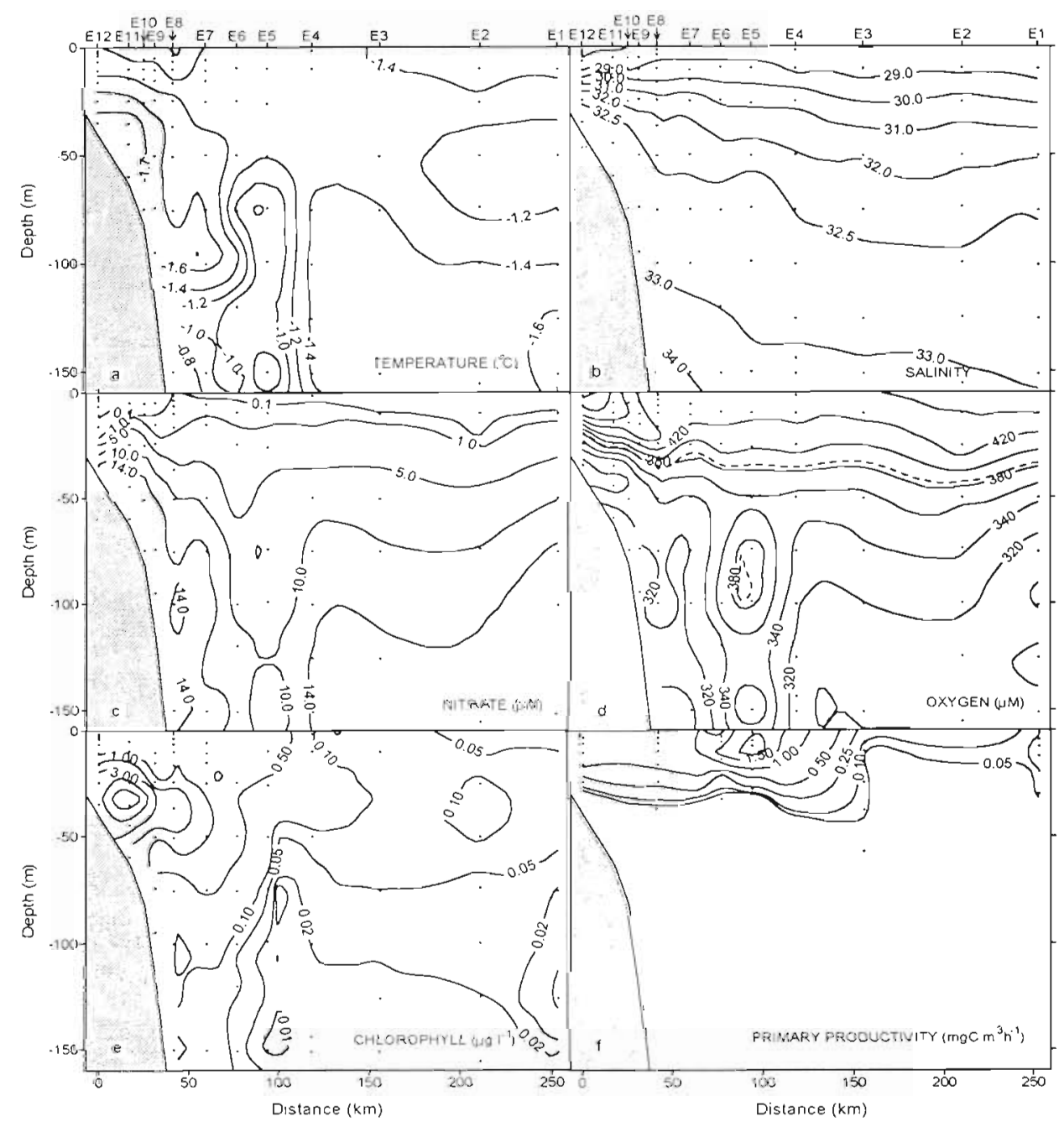

above the chlorophyll biomass maximum (Fig. 3), however there were regional differences. At 4 stations over the continental slope $(<200 \mathrm{~m})$, maximum photosynthetic rates usually occurred well above the chlorophyll maximum. A subsurface photosynthetic maximum was found between 4 and $22 \mathrm{~m}$, while the chlorophyll maximum was between 31 and $58 \mathrm{~m}$, usually at light intensities of 0.1 to $0.001 \% I_{0}$. The photosynthetic maximum was just above the chlorophyll maximum, and the top of the nutricline was observed over the upper slope. At 2 of 3 stations over the lower slope, with total depths $>2000 \mathrm{~m}$, the photosynthetic maximum was below the chlorophyll maximum, and at 1 of the 3 it was above the chlorophyll maximum. In all 3, the photosynthetic maximum was in the top of the nutricline.

Fig. 3. Vertical distributions of chl a, primary production and biomass-specific production during August, 1993 at expermental stations $(n=12)$ in the Chukchi Sea. Production estimates were based on 22 to $26 \mathrm{~h}$ incubations. Values shown are means $\pm 1 \mathrm{SE}$

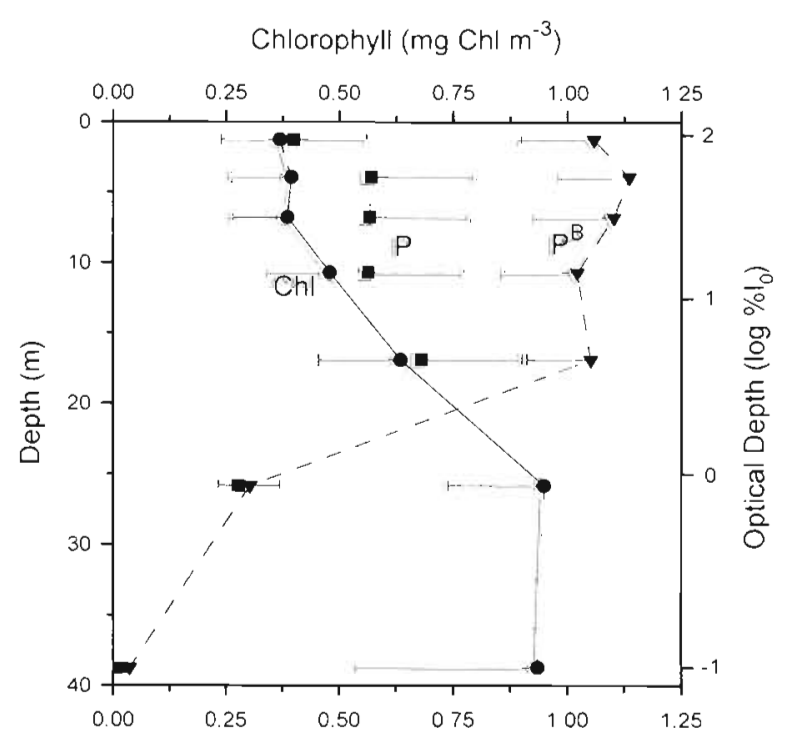

Primary Production $\mathrm{P}\left(\mathrm{mg} \mathrm{C} \mathrm{m}^{-3} \mathrm{~h}^{-1}\right)$ Specific Production $P^{B}\left[m g C(m g C h l)^{-1} h^{-1}\right]$ 
Table 2. Euphotic zone integrations of primary production ( $6108 \mathrm{~h}$ incubations), microbial community respiration (comm. resp.) and bacterial (bact.) production, and standing stocks of particulate organic carbon (POC) in the Chukchi Sea. $\mathrm{P} / \mathrm{R}$ is ${ }^{14} \mathrm{C}$ production versus respiration. New production is based on ${ }^{13} \mathrm{C}$ and ${ }^{15} \mathrm{~N}$ : $\mathrm{f}$-ratio assumes an ammonium concentration of $0.1 \mu \mathrm{M}$. Euphotic depth $=0.1 \% I_{0}$

\begin{tabular}{|c|c|c|c|c|c|c|c|c|c|c|c|c|}
\hline Stn & $\underset{N}{\text { Latitude }}$ & $\begin{array}{c}\text { Longitude } \\
\text { W }\end{array}$ & $\begin{array}{l}\text { Total } \\
\text { depth } \\
(\mathrm{m})\end{array}$ & $\begin{array}{l}{ }_{{ }^{14} \mathrm{C}}^{\text {Primary }} \mathrm{C} \mathrm{m}^{-2} \\
\end{array}$ & $\begin{array}{l}\text { prod. } \\
{ }^{2} \mathrm{~d}^{-1}{ }^{-1} \\
{ }^{13} \mathrm{C}\end{array}$ & $\begin{array}{c}\text { Comm. resp. } \\
\text { (mg C m } \mathrm{m}^{-2} \\
\left.\mathrm{~d}^{-1}\right)\end{array}$ & $\begin{array}{l}\text { Euphotic } \\
\text { depth } \\
\text { (m) }\end{array}$ & $\mathrm{P} / \mathrm{R}$ & $\begin{array}{c}\text { Bact. prod. } \\
\text { (mg C m } \\
\left.\mathrm{d}^{-1}\right)\end{array}$ & $\begin{array}{l}\mathrm{POC} \\
(\mathrm{gC} \\
\left.\mathrm{m}^{-2}\right)\end{array}$ & $\begin{array}{l}\% \text { New } \\
\text { prod. }\end{array}$ & f-ratio \\
\hline B1 & $72^{\circ} 00.4^{\prime}$ & $165^{\circ} 18.4^{\prime}$ & 43 & 213 & 215 & 950 & 30 & 0.22 & 13.0 & 4.9 & 12.2 & 0.09 \\
\hline B7 & $73^{\circ} 30.4^{\prime}$ & $167^{\circ} 46.0^{\prime}$ & 118 & 776 & 658 & 835 & 33 & 0.93 & 9.6 & 9.7 & 17.0 & 0.30 \\
\hline $\mathrm{C} 3$ & $74^{\circ} 18.1^{\prime}$ & $167^{\circ} 03.9^{\prime}$ & 281 & 212 & 220 & 426 & 37 & 0.50 & 11.6 & 6.8 & 10.7 & 0.09 \\
\hline C6 & $75^{\circ} 12.2^{\prime}$ & $164^{\circ} 05.3^{\prime}$ & 675 & 316 & 153 & 755 & 41 & 0.42 & 8.8 & 5.6 & 3.6 & 0.12 \\
\hline D1 & $75^{\circ} 22.6^{\prime}$ & $162^{\circ} 58.9^{\prime}$ & 2132 & 181 & 168 & $1 \% 0$ & 41 & 1.03 & 16.4 & 6.4 & 8.8 & 0.06 \\
\hline D3 & $74^{\circ} 48.1^{\prime}$ & $157^{\circ} 24.9^{\prime}$ & 904 & 7.1 & 114 & 350 & 61 & 0.21 & 4.7 & 6.4 & 21.9 & 0.15 \\
\hline E1 & $74^{\circ} 24.6^{\prime}$ & $155^{\circ} 26.2^{\prime}$ & 3811 & 92 & 97 & 244 & 45 & 0.38 & 4.6 & 4.8 & 14.2 & 0.11 \\
\hline E3 & $73^{\circ} 41.1$ & $157^{\circ} 24.4^{\prime}$ & 3440 & 147 & 90 & 1987 & 57 & 0.07 & 7.0 & 3.5 & 19.5 & 0.15 \\
\hline E5 & $73^{\circ} 12.4^{\prime}$ & $158^{\circ} 28.4^{\prime}$ & 1880 & 1492 & 790 & 1152 & 28 & 1.30 & 10.3 & 6.3 & 3.4 & 0.23 \\
\hline E6 & $73^{\circ} 05.3^{\prime}$ & $158^{\circ} 45.1^{\prime}$ & 1.450 & 1069 & 1282 & 533 & 33 & 2.01 & 5.4 & 7.8 & 7.9 & 0.38 \\
\hline E8 & $72^{\circ} 48.6^{\prime}$ & $159^{\circ} 11.7^{\prime}$ & 193 & 651 & 544 & 1025 & 37 & 0.64 & 42.9 & 9.1 & 22.5 & 0.37 \\
\hline E12 & $72^{\circ} 29.9^{\prime}$ & $159^{\circ} 48.4^{\prime}$ & 40 & 613 & 548 & 504 & 25 & 1.22 & 12.2 & 8.6 & 18.8 & 0.05 \\
\hline
\end{tabular}

Rates of vertically integrated primary production in the euphotic zone were not significantly correlated with integrated concentrations of inorganic nutrients $\left[\mathrm{NO}_{3}, \mathrm{Si}(\mathrm{OH})_{4}\right.$ or $\left.\mathrm{PO}_{4}\right]$ or cumulative incident irradiance over the incubation periods. By contrast, areal chlorophyll biomass explained almost half of the variance in ${ }^{14} \mathrm{C}$ primary productivity, but only $21 \%$ of the variability in the ${ }^{13} \mathrm{C}$ values. Nevertheless, there was generally good agreement between our estimates of ${ }^{14} \mathrm{C}$ and ${ }^{13} \mathrm{C}$ productivity (Table 2 ).

The integrated mean photosynthetic rate over the cruise track was $295 \pm 81 \mathrm{mg} \mathrm{C} \mathrm{m}{ }^{-2} \mathrm{~d}^{-1}$ (mean $\pm 1 \mathrm{SE}_{i}$ $n=12$ ) based on 22 to $26 \mathrm{~h}$ incubations. However, regional differences in photosynthesis along the cruise track were marked, especially in the deeper waters. Photosynthesis over the continental shelf was 102 to $486 \mathrm{mg} \mathrm{C} \mathrm{m}{ }^{-2} \mathrm{~d}^{-1}$ (mean $=336 ; \mathrm{n}=4$ ), but photosynthesis was highest over the upper continental slope, in water depths from 200 to $2000 \mathrm{~m}$, ranging from 45 to $950 \mathrm{mg} \mathrm{C} \mathrm{m} \mathrm{m}^{-2} \mathrm{~d}^{-1}$ (mean $=394 ; \mathrm{n}=5$ ). Photosynthesis in the Canadian Basin at depths $>2000 \mathrm{~m}$, and with $>50 \%$ ice cover, ranged from 47 to $120 \mathrm{mg} \mathrm{C} \mathrm{m}^{-2} \mathrm{~d}^{-1}$ ( mean $=74 ; \mathrm{n}=3)$. Note primary production values in Table 2 are short-term not daily values.

\section{Heterotrophic activity}

Rates of bacterial assimilation of ${ }^{14} \mathrm{C}$-leucine into protein were $>3$ pMl leucine $\mathrm{l}^{-1} \mathrm{~h}^{-1}$ over the continental shelf generally, with rates up to $26 \mathrm{pM}$ leucine $\mathrm{l}^{-1} \mathrm{~h}^{-1}$ at Stn E8 (Table 1). Rates then decreased beyond E5 and were around $1 \mathrm{pM}$ leucine $\mathrm{l}^{-1} \mathrm{~h}^{-1}$ in the Canadian Basin stations. The mean production of bacterial car- bon (Simon \& Azam 1989) for shelf waters was $29.3 \pm$

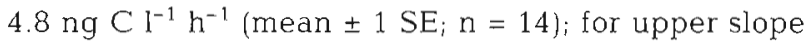
samples it was $9.7 \pm 2.3$; for stations $>2000 \mathrm{~m}$ it was $6.1 \pm$ 1.6. Bacterial production did not necessarily decrease with depth within the mixed layer, but samples taken below $50 \mathrm{~m}$ had a mean of $1.8 \pm 0.8(n=3)$. Since our assumption that uptake was saturated by $10 \mathrm{nM}$ leucine may not be correct, the above rates may underestimate bacterial secondary production. At Stn E7 on the outer continental shelf we ran 1 enrichment experiment of the kind reported by Pomeroy et al. (1995). No limiting substance for bacterial production and respiration, organic or inorganic, was identified. Likewise, no stimulation of primary production was detected for any treatment in parallel enrichment experiments with surface phytoplankton populations held at $100 \%$ incident irradiance for $48 \mathrm{~h}$.

Microbial community respiratory rates in the upper mixed layer did not vary systematically with distance from shore or total depth (Table 2). Respiratory rates were never higher in the chlorophyll maximum than in the water above it. The mean rate for the upper $50 \mathrm{~m}$ over the cruise track was $576 \pm 151 \mathrm{mg} \mathrm{C} \mathrm{m} \mathrm{Cd}^{-1}$ Microbial community respiratory rates were not higher at the stations near the shelf break that had the highest photosynthetic rates. Rates over the shelf and upper slope were almost always measurable, while rates in the upper $50 \mathrm{~m}$ at stations having water depths $>2000 \mathrm{~m}$ in the Canadian Basin and over the Chukchi Cap (in relatively thick ice) sometimes were below our limit of resolution, even in the upper mixed layer and halocline. The limit of resolution depends on the variance within each set of replicate samples, and is approximately $0.03 \mu \mathrm{M} \mathrm{O}_{2} \mathrm{~h}^{-1}$ or $7 \mathrm{mg} \mathrm{C} \mathrm{m} \mathrm{Cd}^{-1}$ (Pom- 
eroy et al. 1994). When photosynthesis and respiratory rates are integrated to the depth of $0.1 \%$ of surface light intensity, $\mathrm{P} / \mathrm{R}\left({ }^{14} \mathrm{C}\right.$ production vs respiration) is seen to be $<1$ at most stations on the continental shelf and at the 3 stations in the Canadian Basin (Table 2). Although we cannot measure it accurately, bacterial assimilation efficiency appears to be low, even if allowance is made for respiration by autotrophs and protozoans and for the possibility that our measurements of bacterial secondary production may underestimate it by a factor of 2 to 3 (see 'Methods'). Low bacterial assimilation efficiency does not appear to be unusual in ocean waters (Griffith et al. 1990, Kirchman et al. 1991, Ducklow 1992, Pomeroy et al. 1995).

Bacteria counts were available only from a limited number of stations near the end of the cruise, because samples had to be returned to a home laboratory and counted before the effects of long-term storage became great (Turley \& Hughes 1992). Samples from the continental shelf and upper continental slope contained $2-5 \times 10^{5}$ bacteria $\mathrm{ml}^{-1}$, with no significant differences between depths or locations.

\section{Oxygen}

Dissolved oxygen was above saturation in all samples taken in the upper mixed layer, with greatest supersaturation near the surface and decreasing with increasing depth (Fig. 2d). At Stn E5, high dissolved oxygen values, near saturation, extended down to 150 $\mathrm{m}$. Similar anomalies of lower nitrate, phosphate, and silicate occurred to $150 \mathrm{~m}$ at Stns E5 and E6 (1450 to $1880 \mathrm{~m}$ ). Temperature, however, showed the reverse, with higher temperatures characteristic of water from around $200 \mathrm{~m}$, penetrating upwards at those stations. Neither salinity nor density showed anomalous distributions at those stations.

\section{DISCUSSION}

While it is certainly true that the highest rates of primary production in the Arctic generally occur around the margins, where sea ice is absent or thin and broken during summer, permitting good penetration of sunlight into the water, we found non-trivial rates of photosynthesis extending far out into the perennial pack ice over deep basin waters. The absence of measurable nitrate in surface waters over the Alaska continental shelf indicates that nitrogen may limit photosynthesis and biomass accumulation in latc summer; however, fratios suggest that regenerated ammonium was available in the upper mixed layer. Beyond the continental shelf, N:P ratios are very low, and nitrate, although usually measurable in near surface waters, is well below the saturation concentration for uptake by large phytoplankton (Smith \& Harrison 1991). At most stations, maximum rates of photosynthesis were found at or near the top of the nutricline. This can be a zone of high ammonium concentrations as well as of nitrate (Smith et al. 1985), and most modeling of Arctic systems assumes an overall seasonal f-ratio of 0.4 to 0.6 (Walsh 1989). However, our estimates of the f-ratio in late summer are lower (Table 2), resembling those reported in the Barents Sea in late summer by Kristiansen et al. (1994). Our measurements of primary production do not take into account the photosynthesis of Melosira clumps, which were evident on the margins of ice floes and in the water all along our cruise track, nor of the photosynthesis by ice algae which takes place mostly within first-year ice, primarily in the spring.

\section{Productivity and respiration}

Relative to oligotrophic systems in lower latitudes, the deep-water stations in the southeastern Chukchi Sea had slightly lower daily rates of photosynthesis, microbial community respiration, and bacterial secondary production. (cf. Pace et al. 1987, Grande et al. 1989, Ducklow 1992, Pomeroy et al. 1995). Although the Arctic Ocean retains the distinction of being the most oligotrophic part of the world's oceans and mediterranean seas, the heterotrophic microbial community appears to be utilizing the in situ primary production nearly as rapidly as it does at lower latitudes. In late summer, we found a net heterotrophic community in much of the upper mixed layer.

Ours was not a seasonal study, so any extrapolation of our data must be done with caution. The Arctic is notorious for irregular, multi-peak seasonal changes in photosynthetic rate (Subba Rao \& Platt 1984), making estimation of annual production difficult. If the supersaturation of oxygen in the upper mixed layer represents photosynthetically produced oxygen, and there is evidence that it does, since little temperature change has occurred, and dissolved $\mathrm{N}_{2}$ is not supersaturated (Codispoti \& Richards 1971), then the excess oxygen found at the end of summer can provide a minimal estimate of photosynthesis by all autotrophic populations over the summer season (Walsh 1989). During the summer, some oxygen is lost to the atmosphere through leads and through the ice (Lyakhin \& Rusanov 1980 , Penta \& Walsh 1995). On the other hand, the excess oxygen in the rater potentially represents net community production (photosynthesis by all autotrophs minus respiration), including clumps of Melosira in the water and all other types of ice algae. At the end of 
Table 3. Annual photosynthesis $\left(\mathrm{g} \mathrm{C} \mathrm{m}^{-2}\right)$ in the Chukchi Sea estimated from excess dissolved oxygen in August 1993. Oxygen above saturation is converted, mole:mole, to equivalent organic carbon

\begin{tabular}{|lcc|}
\hline & Stns E1, E2 & Stns D1, D3 \\
\hline Excess oxygen & 18 & 24 \\
Flux to atmosphere & 9 & 12 \\
Summer respiration & 4 & 4 \\
Total estimated photosynthesis & 31 & 40 \\
\hline
\end{tabular}

summer 1993, the excess dissolved oxygen in the upper $30 \mathrm{~m}$ of the Canadian Basin is equivalent to annual carbon fixation of $18 \mathrm{~g} \mathrm{C} \mathrm{m}^{-2}$. Corrected for losses to the atmosphere (Penta \& Walsh 1995), it corresponds to annual photosynthetic carbon fixation of 27 to $36 \mathrm{~g} \mathrm{C} \mathrm{m}^{-2}$ Adding $30 \mathrm{~d}$ of heterotrophic respiration (assumed to be $50 \%$ of community respiration), the annual primary production is 31 to $40 \mathrm{~g} \mathrm{C} \mathrm{m}^{-2}$ (Table 3). In these calculations we assumed the photosynthetic quotient (PQ) to be 1.2. The estimate that includes only supersaturation and diffusive losses should be a minimal estimate of new production.

New production can also be estimated from the observed late summer nutrient depletion. We assume that winter equilibrium concentrations of nitrate are about $10 \mu \mathrm{M}$ similar to the values at $50 \mathrm{~m}$. Nitrate levels in the upper $20 \mathrm{~m}$ averaged $<1 \mu \mathrm{M}$, and from 20 to $40 \mathrm{~m}$ concentrations were $<5 \mu \mathrm{M}$ (Fig. 2). Therefore, about $280 \mathrm{mmol} \mathrm{NO} \mathrm{m}^{-2}$ were utilized from the upper water column. Employing a $C: N$ ratio of 6.6 implies that annual new production was $18.5 \mathrm{~g}$ $\mathrm{C} \mathrm{m}^{-2}$. In similar fashion Macdonald et al. (1987) predicted annual new production rates of 16 and $23 \mathrm{~g} \mathrm{C}$ $\mathrm{m}^{-2}$ for 2 different years in the southeastern Beaufort Sea. More extensive observations in the eastern Canadian Arctic suggest that new production is about half of total annual production (Harrison et al. 1985). Thus, a total annual primary production at $37 \mathrm{~g} \mathrm{C} \mathrm{m}^{-2}$ falls within the range predicted from oxygen supersaturation above (also see Table 3). Vertical mixing would tend to increase nitrate supply, while dilution by melting sea ice has the opposite effect. No corrections have been made for these or other processes such as regeneration, which could alter these simple estimates.

For comparison, if we assume conservatively that the mean mid-August photosynthetic rate measured with ${ }^{14} \mathrm{C}$ and ${ }^{13} \mathrm{C}$ at stations in the Canadian Basin and Northwind Ridge and Plain (E3, E1, D3, D1) of 123.5 $\mathrm{mg} \mathrm{C} \mathrm{m} \mathrm{m}^{-2} \mathrm{~d}^{-1}$ is a representative daily rate, we get an estimate of annual photosynthesis of 11 to $15 \mathrm{~g}$ assuming growing seasons of 90 to $120 \mathrm{~d}$. This, of course, is probably an underestimate because of decreased nutrient availability and species succession seasonally. A pronounced phytoplankton bloom earlier in the season. with higher daily photosynthetic rates may be more typical. For example, recent evidence indicates that Phaeocystis can have elevated photosynthetic rates and be a major early producer elsewhere in the Arctic (Smith et al. 1991, Cota et al. 1994). Additional contributions by Melosira and other ice algae also would increase annual primary productivity. Much less is known about Melosira and ice algae in the pack ice. While our estimates based on excess oxygen and nutrient depletion are very crude and probably minimal, they suggest that there is a band of significant primary production extending well beyond the continental shelves into the perennial pack ice over deep waters, at least $300 \mathrm{~km}$ from the Alaskan shore. Photoautotrophic activities must diminish considerably where multi-year ice in excess of $2 \mathrm{~m}$ in thickness normally covers most of the water's surface, because light levels will be below compensation intensities for net primary production.

However, the idea that the Arctic Ocean is a biological desert because of its 'permanent' ice cover can be very misleading. The ice cover is rarely continuous even in winter, and there can be significant amounts of open water anywhere in the pack ice zone during summer. Almost a decade of passive-microwave observations suggests that by August ice cover concentrations often fall below $80 \%$, and even to $<50 \%$ in some years, over much of our study area (Gloersen et al. 1992). Passive-microwave observations cannot distinguish between melt ponds and open water, so concentrations may be underestimated when ponding is extensive. August 1993 appeared to be a relatively light ice year with 20 to $40 \%$ open water in many areas and few melt ponds. Ice reconnaissance flights by helicopter indicated that heavy ice cover was prevalent (but not continuous) north of approximately $76^{\circ} \mathrm{N}$, just beyond the range of our cruise track.

Intense biological activity was evident throughout most of our study area. Oxygen was supersaturated and nitrate levels were $<1 \mu \mathrm{M}$ in the upper $20 \mathrm{~m}$ at our most northern station. Lyakhin \& Rusanov (1983) show summer supersaturation to be widespread in the Arctic Ocean, including regions of multi-year pack ice cover (see review by Pomeroy 1996). English (1961) found the upper mixed layer to be supersaturated with dissolved oxygen from July 8 until he terminated sampling October 15. An estimate of primary production similar to our estimate above, based on English's dissolved oxygen data, suggests that the annual photosynthetic rate was at least $13 \mathrm{~g} \mathrm{C} \mathrm{m}^{-2}$ at Drift Station Alpha in 1958 . That station was near $85^{\circ} \mathrm{N}$ in the multiyear ice pack, and nitrate was $<1 \mu \mathrm{M}$ in surface waters by August. 


\section{Heterotrophic processes}

Estimating annual community respiration in the Arctic Ocean is problematic. The relative uniformity of community respiratory rates over our entire cruise track and the lack of coherence of community respiration with photosynthetic rates suggest a large component of bacterial respiration. Numbers of bacteria in the water also showed little variation, not only during our 1993 cruise but at other sites and seasons as well (i.e. Harrison et al. 1987, Pomeroy et al. 1990). Although microbial community respiration occurs throughout the year at all depths, and will be little affected by the small seasonal differences in temperature, it may well be affected by seasonal and regional differences in the standing stocks of phytoplankton, which are one component of community respiration and are also the primary source of organic carbon for heterotrophic respiration. Standing stocks of labile organic matter must decrease during the long winter season. This may have a pronounced effect on bacterial respiration and production, if the bacterial community has difficulty utilizing very low substrate concentrations at the low temperature (Wiebe et al. 1992)

If, however, we extrapolate the microbial community respiratory rate observed in August over 7 winter months, it would be equivalent to microbial utilization of $12 \mathrm{~g} \mathrm{C} \mathrm{m}^{-2}$ for the upper $50 \mathrm{~m}$. This implies that dissolved oxygen in the upper mixed layer will be about $90 \%$ saturated in early spring, possibly a bit lower than expected from observations (English 1961, Lyakhin \& Rusanov 1983, data from Sverdrup as re-examined in Penta \& Walsh 1995). At a 7:1 ratio of $C: N$, this is equivalent to remineralization of $5.6 \mu \mathrm{MN} \mathrm{N}^{-1}$, which is approximately the winter-spring nitrate concentration in the upper halocline at the T-3 and CESAR sites (Macdonald et al. 1987). That estimate does not include respiration of organisms large and active enough to escape a Niskin sampler, such as many copepods. Nevertheless it is probably an overestimate which may serve to put an upper limit on the extent to which biological activity may alter concentrations of dissolved oxygen, nitrate, and phosphate in the upper $50 \mathrm{~m}$.

\section{Rate variations over time and space}

Data from the CESAR site over the Alpha Ridge suggest that metabolic rates of living organisms and standing stocks of organic materials in the water column continue to decrease at greater distances from the continental marqins. For example. POC in the imner $50 \mathrm{~m}$ at the CESAR site was $13.8 \mathrm{\mu g} \mathrm{l}^{-1}$ (Gordon \& Cranford 1985). However, not all Arctic continental shelves are highly productive. At the Canadian Ice Is- land, situated in very thick ice on the outer continental shelf north of Ellef Ringness Island, POC was $1.2 \mu \mathrm{g} \mathrm{l}^{-1}$ in June and 8.5 in late August (Hargrave et al. 1989). These values can be compared with a mean of $117 \pm$ $4 \mathrm{~kg} \mathrm{l}^{-1}(\mathrm{n}=19)$ from our basin stations E1 and D3, and $270 \pm 14(n=40)$ for our shelf stations E8, E12, B1, and B7. At the Canadian Ice Island in June 1988 (prethaw), bacterial secondary production in the upper $50 \mathrm{~m}$, measured by the uptake of ${ }^{3} \mathrm{H}$-leucine, was $0.2 \mathrm{ng} \mathrm{Cl} \mathrm{l}^{-1} \mathrm{~d}^{-1}$ (Pomeroy et al. 1990), compared with a mean of $120 \pm 3.9(n=5)$ for our stations E1 and D3.

We do not have the necessary sensitivity to measure short-term respiratory rates in the upper mixed layer beneath multi-year ice. From the chlorofluoromethane distribution at the CESAR site, Wallace et al. (1987) estimated the apparent oxygen utilization (AOU) in the cold halocline, 55 to $155 \mathrm{~m}$, to be 0.016 to $0.042 \mu \mathrm{M} \mathrm{O}_{2}$ $\mathrm{m}^{-2} \mathrm{~s}^{-1}$, or 4.8 to $12.7 \mathrm{~g} \mathrm{C} \mathrm{m}^{-2} \mathrm{yr}^{-1}$. On the basis of the usual low estimate of primary production in the central Arctic basins, they attribute all of the organic supply to the continental shelves. However, our revised estimates would permit most of their AOU estimate to originate in the immediate water column during summer, although it seems reasonable to assume that some organic matter originates both in the local water column and on the shelves.

Our results show that the upper $50 \mathrm{~m}$ of the Chukchi Sea are biologically dynamic, not only on the continental shelves but in the waters over the continental slope and in the Canadian Basin, at least up to the region of heavy multi-year ice cover. The physically dynamic events along the continental slope are not only those of seasonal melting and retreat of the ice pack but also vertical advection of nutrients by currents and edge waves (Johnson 1989, Aagaard \& Roach 1990). The effects of these kinds of events are seen in our data from the upper continental slope, where active vertical water movement had recently occurred or was occurring down to 150 to $200 \mathrm{~m}$ (Fig 2). This was also the region of highest biological activity at the time of our August cruise. Much of the primary production is, however, being utilized rapidly in the heterotrophic food web. At the stations aver the upper continental slope photosynthesis significantly exceeded community respiration in August, but at all other stations, both on the continental shelf and in the deep, oligotrophic waters of the Canadian Basin, microbial community respiration usually exceeded primary production (Table 2). Photosynthesis probably exceeded community respiration early in the season, when nitrate exceeds saturation for large phytoplankters. This differs from later primary production not only quäintitatively, but also qualitatively (Andersen 1988, Walsh et al. 1989), with the major producers during blooms being larger diatoms or Phaeocystis that tend to aggre- 
gate and sink, at least into the pycnocline, before being utilized (Smetacek \& Pollehne 1986, Smith et al. 1991). Later in the season, the dominant primary producers are mostly $<10 \mu \mathrm{m}$, their consumers are likely to be protozoans, whose feces and other particulate products of the heterotrophic food web sink slowly, if at all, and will not penetrate the density barrier presented by the halocline. Organic materials accumulate, and their regeneration produces the nutrient maximum-oxygen minimum. In late summer, most of the photosynthesis is probably dependent upon ammonium. This hypothesis is supported by our estimatcs of the f-ratio of 0.05 to 0.38 (Table 2). It also is reflected in English's (1961) dissolved oxygen data. Oxygen begins to rise above saturation in July but reaches a plateau on or about mid-August, remaining above saturation until October. This would happen if new production occurred largely during the first 20 to $30 \mathrm{~d}$ of the productive season.

The recognition of higher biological activity than previously assumed in the upper mixed layer of the Arctic Ocean does not eliminate the possibility of lateral transport of organic matter from the continental shelves during winter. Walsh et al. (1989) postulate that organic matter sinks to the bottom of continental shelves in late spring-early summer at the time of the phytoplankton bloom and is then transported into the basin along isopycnals in winter by the production and transport of cold brine. While observing these phenomena has proven to be elusive (Aagaard \& Roach 1990), there is indirect evidence that shelf-derived brines contribute to the maintenance of the halocline. The cold brine is transported along isopycnals for probably 20 to $40 \mathrm{yr}$ into the central basin (Jones \& Anderson 1986, Wallace et al. 1987). Wallace et al. (1987) say that most of the AOU observed in. the cold halocline in the central basin may, in fact, have occurred very early while the water is over or near the continental shelves, and the rates of respiration we have observed would support that supposition.

The need to invoke long-term, long distance transport of labile organic matter is based on the assumption that photosynthesis in the central Arctic basin is not sufficient to support the AOU observed there (Jones \& Anderson 1986, Wallace et al. 1987). Yet we really have very few direct measurements of photosynthesis in the region of perennial multi-year pack ice, beyond the early work at Drift Station Alpha by English (1961). Based on simulated in situ measurements with ${ }^{14} \mathrm{C}$, using fluorescent lights and Wratten filters, the use of metal or rubber devices for collecting seawater (Price et al. 1986), and a number of other practices of the time that probably led to an underestimate (cf. Fitzwater et al. 1982), English's ${ }^{14} \mathrm{C}$ measurements of primary production in the multi-year ice of the central basin frequently have been interpreted to suggest rates on the order of 1 to $5 \mathrm{~g} \mathrm{C} \mathrm{m}^{-2}$ As we have noted, English's (1961) dissolved oxygen data yield an independent estimate of annual primary production of at least $13 \mathrm{~g} \mathrm{C} \mathrm{m}^{-2}$ Most oxygen-based estimates of annual primary production in the Arctic suggest values of 13 to $38 \mathrm{~g} \mathrm{C} \mathrm{m}^{-2}$ are more reasonable (Pomeroy 1996). According to the models of Wallace et al. (1987), the minimal approximation of AOU for the upper $55 \mathrm{~m}$ should be $4 \mathrm{~g} \mathrm{C} \mathrm{m}^{-2}$ for 4 summer months, an amount which may be supported by local primary production. This diminishes considerably the amount of labile organic carbon that must be transported laterally over the course of decades of time. Indeed, the errors around these estimates are so large, they do not eliminate the possibility that the central polar basin produces enough organic carbon to balance AOU (Pomeroy 1996). We reiterate the statement of Subba Rao \& Platt (1984) that more data are needed from the offshorc regions of the Arctic Ocean. Seasonal dynamics of biological communities and ice cover are critical to better understand the productivity of polar regions.

Acknowledgements. Our research was supported by grants DPP 9122887 (G.F.C.) and DPP 9223007 (L.R.P.) from the U.S. National Science Foundation and grant No0014-93-1-0976 (G.F.C. and L.R.P.) from the U.S. Office of Naval Research. Additional support was provided by the Canadian Department of Fisheries and Oceans. We thank L. Cooper, Chief Scientist, and J. Grebmeier for their support and cooperation during the cruise. Amino acid analyses were done by Joan Sheldon.

\section{LITERATURE CITED}

Aagaard K, Roach AT (1990) Arctic Ocean-shelf exchange: measurements in Barrow Canyon. J Geophys Res 95C: 18163- 18175

Andersen P (1988) The quantitative importance of the 'Microblal loop' in the marine pelagic: a case study from the North Bering/Chukchi seàs. Arch Hydrobiol Beih Ergebn Limnol 31:243-251

Björk G (1990) The vertical distribution of nutrients and oxygen 18 in the upper Arctic Ucean. J Geophys Res 95C: $16025-16036$

Codispoti LA, Richards FA (1971) Oxygen supersaturation in the (hukchi and East Siberian Seas. Deep Sea Res 18: $341-351$

Cota GF, Smith WO Jr, Mitchell BG (1994) Photosynthesis of Phaeocystis in the Greenland Sea. Limnol Oceanogr 39: 948-953

Ducklow HW (1992) Oceanic bacterial production. In: Marshall KC (ed) Advances in microbial ecology. Plenum Press, New York, p 12133-12181

Dugdale RC. Goering JJ (1967) Uptake of new and regenerated forms of nitrogen in primary productivity. Limnol Oceanogr 12:196-206

English TS (1961) Some biological oceanographic observations in the central North Polar Sea. Drift Station Alpha, 1957-1958. Arctic Institute of North America, Res Paper 13 
Fitzwater SE, Knauer GA, Martin JH (1982) Metal contamination and its effect on primary production measurements. Limnol Oceanogr 27:544-551

Gloersen P, Campbell WJ, Cavalieri DJ, Comiso JC, Parkinson CL, Zwally HJ (1992) Arctic and Antarctic sea ice, 1978-1987: satellite passive-microwave observations and analysis. NASA SP-511, Washington, DC

Gordon DC, Cranford PJ (1985) Detailed distribution of dissolved and particulate organic matter in the Arctic Ocean and comparison with other oceanic regions. Deep Sea Res 32:1221-1232

Grande KD, Williams PJ leB, Marra J, Purdie DA, Heinmann K, Eppley RW. Bender ML (1989) Primary production in the North Pacific gyre: a comparison of rates determined by the ${ }^{14} \mathrm{C}, \mathrm{O}_{2}$ concentration, and ${ }^{18} \mathrm{O}$ methods. Deep Sea Res 36:1621-1634

Griffith PC, Douglas DJ, Wainright SC (1990) Metabolic activity of size-fractionated microbial plankton in estuarine, nearshore, and continental shelf waters of Georgia. Mar Ecol Prog Ser 59:263-270

Hama T, Miyazaki T, Ogawa Y, Iwakuma T, Takahashi M, Otsuki A, Ichimura S (1983) Measurement of photosynthetic production of a marine phytoplankton population using a stable ${ }^{13} \mathrm{C}$ isotope. Mar Biol 73:31-36

Hargrave BT, von Bodungen B. Conover RJ, Fraser AJ, Phillips G, Vass WP (1989) Seasonal changes in sedimentation of particulate matter and lipid content of zooplankton collected by sediment trap in the Arctic Ocean off Axel Heiberg Island. Polar Biol 9:467-475

Harrison WG (1986) Respiration and its size-dependence in microplankton populations from surface waters of the Canadian Arctic. Polar Biol 6:145-152

Harrison WG, Head EJH, Conover RJ, Longhurst AR, Sameoto DD (1985) The distribution and metabolism of urea in the eastern Canadian Arctuc. Deep Sea Res 32: $23-42$

Harrison WG, Li WKW, Smith JC, Head EJH, Longhurst AR (1987) Depth profiles of plankton, particulate organic matter and microbial activity in the Eastern Canadian Arctic during summer. Polar Biol 7:207-224

Henrichs SM, Williams PM (1985) Dissolved and particulate amino acids and carbohydrates in the sea surface microlayer. Mar Chem 17:141-163

Hobbie JE, Daley RJ, Jasper S (1977) Use of Nuclepore filters for counting bacteria by fluorescence microscopy. Appl Environ Microbiol 33:1225-1228

Holm-Hansen O, Lorenzen CJ, Hoimes RW, Strickland JDH (1965) Fluorometric determination of chlorophyll. J Cons perm int Explor Mer 30:3-15

Johnson WR (1989) Current response to wind in the Chukchi Sea: a regional coastal upwelling event. J Geophys Res 94C:2057-2064

Jones EP, Anderson LG (1986) On the origin of the chemical properties of the Arctic Ocean halocline. J Geophys Res 91C:10795-10767

Kirchman DL, Suzuki Y, Garside C, Ducklow HW (1991) Bacterial oxidation of dissolved organic carbon in the North Atlantic Ocean during the spring bloom. Nature 352 : 612-614.

Kristiansen S, Farbrot T, Wheeler PA (1994) Nitrogen cycling in the Barents Sea - seasonal dynamics of new and regenerated production in the marginal ice zone. Limnol Oreanogr 39:1630-1642

Lindroth P, Mopper K (1978) High performance liquid chromatographic determination of subpicomole amounts of amino acids by precolumn fluorescence derivatization with o-phthalaldehyde. Analyt Chem 51:1667-1674
Logan BE, Fleury RC (1993) Multiphasic knnetics can be an artifact of the assumption of saturable kinetics for microorganisms. Mar Ecol Prog Ser 102:115-124

Lyakhin YI, Rusanov VP (1980) Oxygen and carbon dioxide exchange between the Arctic basin and the atmosphere. Oceanology 20:411-418

Lyakhin YI, Rusanov VP (1983) Exchange of oxygen and $\mathrm{CO}_{2}$ between water and atmosphere in the Arctic seas. Oceanology 23:722-726

Macdonald RW, Wong CS, Erickson, PE (1987) The distribution of nutnents in the southeastern Beaufort Sea: implications for water circulation and primary production. J Geophys Res 92C: 2,939-2,952

MCRoy CP (1993) ISHTAR, the project: an overview of inner shelf transfer and recycling in the Bering and Chukchi Seas. Cont Shelf Res 13:473-479

Mopper K, Lindroth P (1982) Diel and depth variations in dissolved free amino acids and ammonium in the Baltic Sea determined by shipboard HPLC analysis. Limnol Oceanogr 27:336-347

Pace ML, Knauer GA, Karl DM, Martin JH (1987) Primary production, new production and vertical flux in the eastern Pacific Ocean. Nature 325:803-804

Parsons TR, Maita Y, Lalli CM (1984) A manual of chemical and biological methods for seawater analysis. Pergamon Press, New York

Penta B, Walsh JJ (1995) A one-dimensional ecological model of summer oxygen distributions within the Chukchi Sea. Cont Shelf Res 15:337-356

Platt T, Harrison WG, Horne EPW, Irwin B (1987) Carbon fixation and oxygen evolution by phytoplankton in the Canadian high Arctic. Polar Biol 8:103-113

Pomeroy LR (1996) Primary production in the Arctic Ocean estimated from dissolved oxygen. J Mar Syst (in press)

Pomeroy LR, Macko SA, Ostrom PH, Dunphy J (1990) The microbial food web in Arctic seawater: concentration of dissolved free amino acids and bacterial abundance and activity in the Arctic Ocean and in Resolute Passage. Mar Ecol Prog Ser 61:31-40

Pomeroy LR, Sheldon JE, Sheldon WM Jr (1994) Changes in bacterial numbers and leucine assimilation during estmmations of microbial respiratory rates in seawater by the precision Winkler method. Appl Environ Microbiol 60 $328-332$

Pomeroy LR, Sheldon JE, Sheldon WM Jr, Peters F (1995) Limits to growth and respiration of bacterioplankton in the Gulf of Mexico. Mar Ecol Prog Ser 117:259-268

Price NM, Harrison PJ, Landry MR, Azam F, Hal.. KJF (1986) Toxic effects of latex and Tygon tubing on marine phytoplankton, zooplankton and bacteria. Mar Ecol Prog Ser 34: $41-49$

Simon M, Azam F (1989) Protein content and protein synthesis rates of planktonic marine bacteria. Mar Ecol Prog Ser 51:201-213

Smetacek V, Pollehne F (1986) Nutrient cycling in pelagic systems: a reappraisal of the conceptual framework. Ophelia $26: 401-428$

Smith SL, Smith WO Jr, Codispoti LA, Wilson DL (1985) Biological observations in the marginal ice zone of the East Greenland Sea. J Mar Res 43:693-717

Smith WO Jr, Codispoti LA, Nelson DM, Manley T, Buskey EJ, Niebauer HJ, Cota GF (1991) Importance of Phaeocystis blooms in the high-latitude ocean carbon cycle. Nature 352:514-515

Smith WO Jr, Harrison WG (1991) New production in polar regions. The role of environmental controls. Deep Sea Res 38:1463-1479 
Subba Rao DV, Platt $T$ (1984) Primary production in Arctic waters Polar Biol 3:191-201

Turley CM, Hughes DJ (1992) Effects of storage on direct estimates of bacterial numbers of preserved seawater samples. Deep-Sea Res 39:375-394

van Loolj A, Riemann B (1993) Measurements of bacterial production in coastal marine environments using leucine: application of a kinetic approach to correct for isotope dilution. Mar Ecol Proy Ser 102:97-104

Wallace DWR, Moore RM, Jones EP (1987) Ventilation of the Arctic Ocean cold halocline: rates of diapycnal and isopycnal transport, oxygen utilization and primary production inferred using chlorofluoromethane distributions. Deep Sea Res 34:1957-1979

This article was presented by S. Y Newell (Senjor Editorial Advisor), Sapelo Island, Georgia, USA
Walsh JJ (1989) Arctic carbon sinks: present and future. Global Biogeochem Cycles 3:393-411

Walsh J.J, McRoy CP, Coachman LK, Goering JJ, Nihoul JJ, Whitledge TE, Blackburn TH, Parker PL, Wirick CD, Shuert PG, Grebmeier JM, Springer AM, Tripp RD, Hangel DA, Djenidi S, Deleersmijder E, Henriksen K, Lund BA, Andersen P, Müller-Karger FE, Dean K (1989) Carbon and nitrogen cycling within the Bering-Chukchi Seas: source regions for organic matter effecting AOU demands of the Arctic Ocean. Prog Oceanogr 22: $277-359$

Wiebe WJ, Sheldon WM Jr, Pomeroy LR (1992) Bacterial growth in the cold: evidence for an enhanced substrate requirement. Appl Environ Microbiol 58:359-364

Manuscript first received: June 12, 1995

Revised version accepted: October 30,1995 